\title{
Dynamic deformation of high pressure die-cast magnesium alloys $^{(\cdot)}$
}

\author{
N.V. Dudamell*, F. Gálvez** and M.T. Pérez-Prado*
}

\begin{abstract}
The dynamic behavior of the die-cast Mg-6 \% Al- $0.5 \% \mathrm{Mn}$ and $\mathrm{Mg}-9 \% \mathrm{Al}-1 \% \mathrm{Zn}$ alloys has been investigated in a wide range of temperatures and compared to the quasi-static behavior. It has been found that, at high strain rates, these alloys possess very good energy absorption capacity and that twinning is significantly enhanced. The small variability in the tensile ductility at dynamic rates is attributed to the independence of the adiabatic shear failure mechanism of the porosity distribution.
\end{abstract}

\section{Deformación dinámica de aleaciones de magnesio coladas por inyección a alta presión}

\begin{abstract}
Resumen
El comportamiento dinámico de las aleaciones de magnesio Mg-6 \% Al-0,5 \% Mn y Mg-9 \% Al-1 \% Zn ha sido investigado en un amplio intervalo de temperaturas y se ha comparado con el comportamiento cuasi-estático. Se ha encontrado que, a altas velocidades de deformación estas aleaciones poseen alta capacidad de absorción de energía y que se mejora el maclado significativamente. Las pequeñas variaciones en la ductilidad a tracción a velocidades dinámicas se atribuyen a la independencia de de los mecanismos de cizalla adiabática de la distribución de la porosidad.
\end{abstract}

Palabras clave Magnesio; Alta velocidad de deformación; Maclado; AM60; AZ91.

\section{INTRODUCTION}

High pressure die casting (HPDC) is one of the most widely spread technologies to form lightweight parts of magnesium alloys for automotive applications due to its low cost and high volume production of near net shape parts ${ }^{[1]}$. AZ91 and AM60 are the most common die-cast alloys, as the former has excellent castability and strength and the latter outstanding ductility and energy absorbing properties. Several studies have aimed to relate the microstructure and the mechanical behavior of HPDC Mg alloys, especially of the AZ and AM series, at quasi-static strain rates ${ }^{[2-11]}$. However, the mechanical properties of HPDC alloys are less predictable than those of wrought products because key microstructural parameters such as the distribution of second phases and the volume fraction, the shape and distribution of pores depend strongly on the solidification conditions ${ }^{[12 \text { and } 13]}$, which change during processing and are, thus, hard to reproduce and control.

Before die-cast magnesium parts can be utilized for automobile structural applications, they must fulfill strict requirements towards energy absorption during crash conditions. In recent years some studies have investigated the dynamic mechanical behavior of wrought magnesium alloys, either extruded or rolled ${ }^{[14-26]}$. These works analyze the effect of increasing the strain rate on the yield strength, the UTS, and the elongation to fracture, as well as on the operative deformation mechanisms. The main observations described are an increase in the strain rate sensitivity, in the ductility and in the energy absorbing capability at dynamic rates. An enhancement of the activity of tensile twinning with increasing strain rate has also been reported and this

(•) Trabajo recibido el día 12 de enero de 2012 y aceptado en su forma final el día 10 de septiembre de 2012.

* IMDEA Materials Institute, C/ Profesor Aranguren,s/n, 28040 Madrid, Spain.

** ETS Ingenieros de Caminos, Universidad Politécnica de Madrid, 28040 Madrid, Spain. 
mechanism is suggested to be operative even at rather high temperatures, at which it is not active under quasi-static testing rates. The mechanical behavior of die-cast magnesium alloys at dynamic rates is, however, not well known ${ }^{[27]}$.

The aim of this work is to investigate the mechanical behavior and the operative deformation mechanisms of die-cast AZ91 and AM60 alloys at impact strain rates under a wide range of temperatures in tension and in compression. The influence of the strain rate on the yield strength, the maximum stress, the elongation to failure and the property variability will be described. A comparison between high and low strain rate properties will be established.

\section{MATERIALS AND EXPERIMENTAL PROCEDURE}

The alloys utilized for this study are AZ91D and AM60B. They were purchased in the form of ingots. The latter were melted and die-cast into dog-bone mechanical testing specimens of circular cross-section with a gage length of $12 \mathrm{~mm}$ and a gage diameter of $4 \mathrm{~mm}$. The liquid metal gate velocity was $8-9 \mathrm{~m} / \mathrm{s}$ and the solidification pressure $400-500$ bar. The liquid alloy temperature was $630^{\circ} \mathrm{C}-670^{\circ} \mathrm{C}$ and the temperature of the mould $190{ }^{\circ} \mathrm{C}-230^{\circ} \mathrm{C}$. The microstructure of the die-cast materials was investigated by optical (OM) and scanning electron microscopy (SEM). Sample preparation for these two techniques included grinding with increasingly finer $\mathrm{SiC}$ papers, several diamond polishing steps, and surface finishing using a colloidal silica solution. The specimens prepared for $\mathrm{OM}$ were additionally chemically etched during $15 \mathrm{~s}$ with a solution of $50 \mathrm{ml}$ of ethanol, $0.5 \mathrm{~g}$ of picric acid, $0.5 \mathrm{ml}$ of acetic acid and $1 \mathrm{ml}$ of distilled water. The macrotextures of the die-cast AZ91 and AM60 alloys were measured by the Schulz reflection method in a Philips X'pert-Pro Panalytical X-ray diffractometer furnished with a PW3050/60 goniometer. The radiation used was $\beta$-filtered $\mathrm{Cu} \mathrm{K} \alpha$. The measured incomplete pole figures were corrected for background and defocusing using the Philips X'pert software. The orientation distribution function (ODF), the complete pole figures and the volume fraction of selected texture components were calculated using the MTex software ${ }^{[28]}$. Sample preparation for texture measurement included grinding with $\mathrm{SiC}$ papers of grit sizes ranging from 320 to 2000.

High strain rate mechanical tests $\left(\sim 10^{3} \mathrm{~s}^{-1}\right)$ were carried out using a tensile split Hopkinson bar, equipped with a radiant furnace. Testing temperatures ranged from room temperature to $400^{\circ} \mathrm{C}$, at intervals of $50^{\circ} \mathrm{C}$. Low strain rate tests were performed at room temperature, $200^{\circ} \mathrm{C}$ and $400{ }^{\circ} \mathrm{C}$ at $5 \times 10^{-3} \mathrm{~s}^{-1}$ in a conventional electromechanical Instron testing machine. Two samples were tested for each condition. The heads of the dog-bone die-cast AZ91 and AM60 coupons were threaded in order to be able to screw them to the grips of the testing machines for tension tests. Cylinders of $6 \mathrm{~mm}$ in length were cut out of the gage length of the die-cast dog-bone specimens for the compression tests. The strain to failure $\left(\varepsilon_{\mathrm{f}}\right)$ corresponding to the tests performed in tension $(T)$ and in compression (C) was calculated. In compression tests, $\varepsilon_{f}$ denotes the strain until the maximum stress is reached.

\section{RESULTS AND DISCUSSION}

Figure 1 illustrates the microstructure and the texture of the core region of the as-die-cast AZ91 and AM60 alloys.

The plane examined is perpendicular to the loading axis of the coupons. Microanalysis at the SEM revealed that the phases present in both alloys alloy are mainly $\alpha-\mathrm{Mg}$ (light areas in Fig. 1 ), and $\mathrm{Al}_{12} \mathrm{Mg}_{17}$ (dark areas in Fig. 1). A very small fraction of $\mathrm{Mg}-\mathrm{Al}-\mathrm{Mn}$ compounds were also detected. Both materials have a weak texture. The texture of diecast materials is usually deemed to be completely random. However, here the volume fraction of material with c-axes tilted more than $45^{\circ}$ away from the loading axis $\left(\mathrm{V}_{\mathrm{f}>45^{\circ}}\right)$ in both the AM60 and AZ91 alloys is $\sim 70 \%$. This will result in a tensioncompression asymmetry, which is described below.

Figure 2 summarizes the values of the yield $\left(\sigma_{\mathrm{y}}\right)$ and maximum strengths $\left(\sigma_{\max }\right)$, as well as of the strain to failure $\left(\varepsilon_{f}\right)$, corresponding to the tests performed in tension $(\mathrm{T})$ and in compression $(\mathrm{C})$ at dynamic and quasi-static rates in both alloys. In dynamic tests it is difficult to measure the true yield stress at the nominal strain rate, since in the early stages of deformation the strain rate increases gradually.

Thus, the stress at a true strain of $0.005\left(\sigma_{0.005}\right)$ is used in the present study as a best approximation to this material property. The two die-cast alloys exhibit an excellent mechanical behavior under impact conditions. In general, the room temperature yield and maximum strengths are slightly higher in the dynamic tests than at quasi-static rates, but the values are not very different. The reason for this is that the main operative deformation mechanisms in these weakly textured materials are basal slip and tensile twinning, whose critical resolved shear stresses are strain-rate insensitive. With increasing temperature the values of these two magnitudes decrease, but the change is less pronounced at high strain rate. Thus, 


\section{(a)}
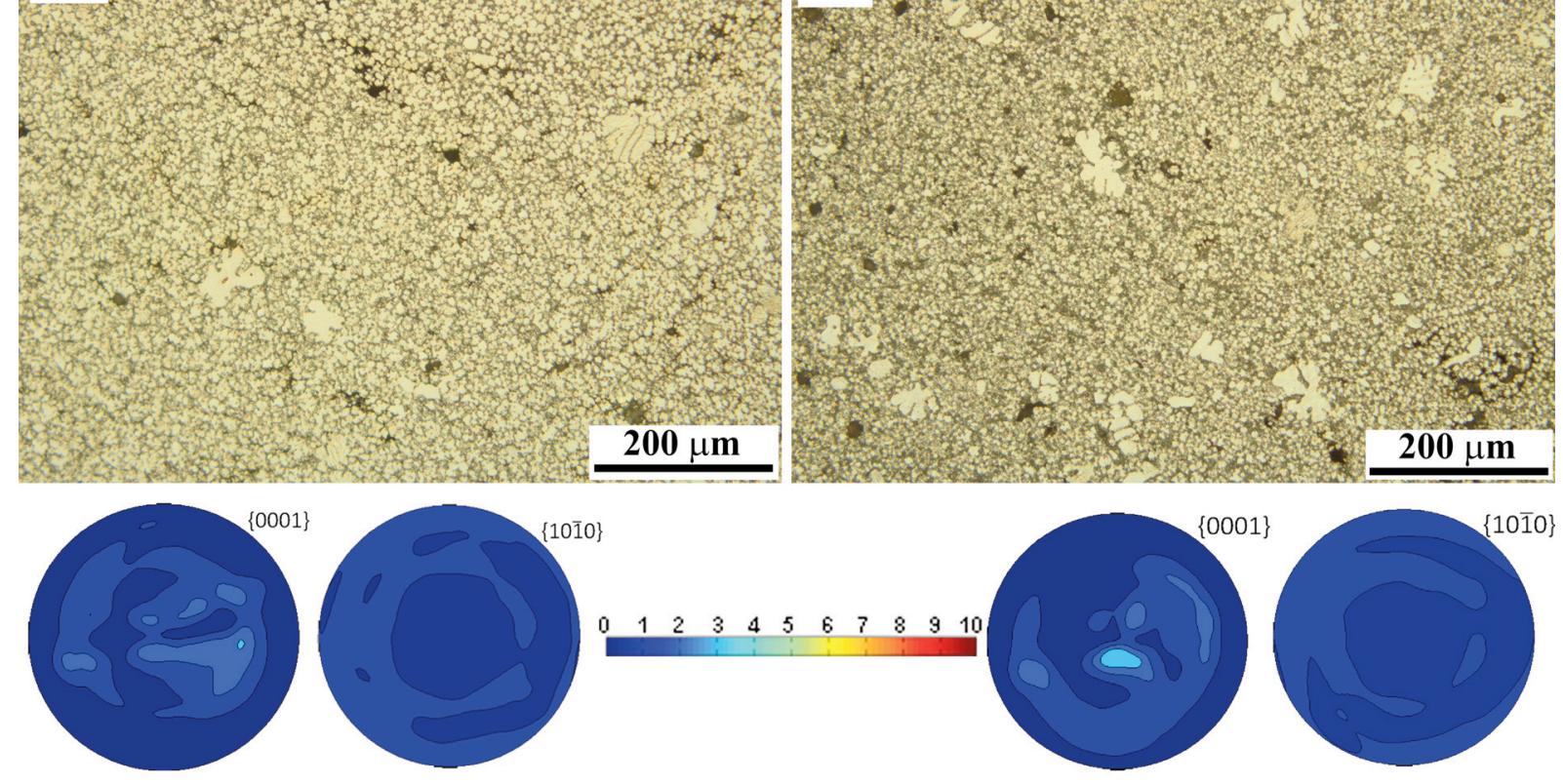

Figure 1. Microstructure and macrotexture (X-ray) of the as-received die-cast magnesium alloy: (a) AM60, (b) AZ91. The plane examined is perpendicular to the loading axis.

\section{Figura 1. Microestructura y macrotextura (Rayos $X$ ) de aleación de magnesio colada por inyección en su estado inicial: (a) AM60, (b) AZ91. El plano examinado es perpendicular al eje de carga.}

the yield and maximum strengths at dynamic rates are significantly higher than those obtained at quasistatic rates at temperatures higher than $200^{\circ} \mathrm{C}$. At $400{ }^{\circ} \mathrm{C}$ and quasi-static rates none of the two alloys experience any work hardening under all the conditions investigated while at dynamic rates a significant amount of work hardening is present. In both alloys the strain to failure increases dramatically with temperature at low strain rates while it remains rather constant at high strain rates. In the AM60 alloy, in the dynamic range, $\varepsilon_{\mathrm{f}}$ retains values close to $20 \%$ in compression and between 10 and $15 \%$ in tension. In the AZ91 alloy the dynamic strain to failure in compression remains in the range between $15 \%$ and $20 \%$ until $350^{\circ} \mathrm{C}$. In tension, it varies between $7 \%$ at room temperature and $5 \%$ at $400{ }^{\circ} \mathrm{C}$. In summary, the two die-cast alloys have a good energy absorption capacity (understood as the area comprised under the stress-strain curve) at dynamic rates within all the temperature range investigated. This is because the decrease in the yield and maximum strengths with temperature are not as pronounced as during quasi-static tests and the strain to failure does not change substantially.

A rather large scatter has been found in the tensile ductility of the AM60 alloy in low strain rate tests
(Fig. 2d)). This is consistent with the results of earlier works $^{[2]}$, which have reported a similar variability of the tensile ductility in a die-cast AM50 alloy deformed in tension at temperatures ranging from $25^{\circ} \mathrm{C}$ to $120^{\circ} \mathrm{C}$. A strong quantitative correlation between the tensile ductility and the area fraction of the porosity in the corresponding fracture surfaces was found. However, the ductility was not reported to be related to the pore volume fraction. Thus, higher ductility values are predicted to be present in tensile specimens with a smaller number of large gas pores and/or of clustered small pores. $\operatorname{In}^{[2]}$ the extent of the variability was observed to decrease with temperature. The authors did not report the reason for this decrease but they put forward several possible explanations such as variations in the strain hardening rate with temperature or plastic relaxation due to the activation of secondary slip systems at high temperatures. In the present work the tensile ductility shows great variability until temperatures as high as $400^{\circ} \mathrm{C}$. The differences between the two studies might be due to the use of different solidification conditions, which might result in drastic variations in the porosity distribution. Additionally, no significant variability was found in the tensile ductility of the AZ91 alloy at quasi-static rates (Fig. 2 h)). It has been reported 

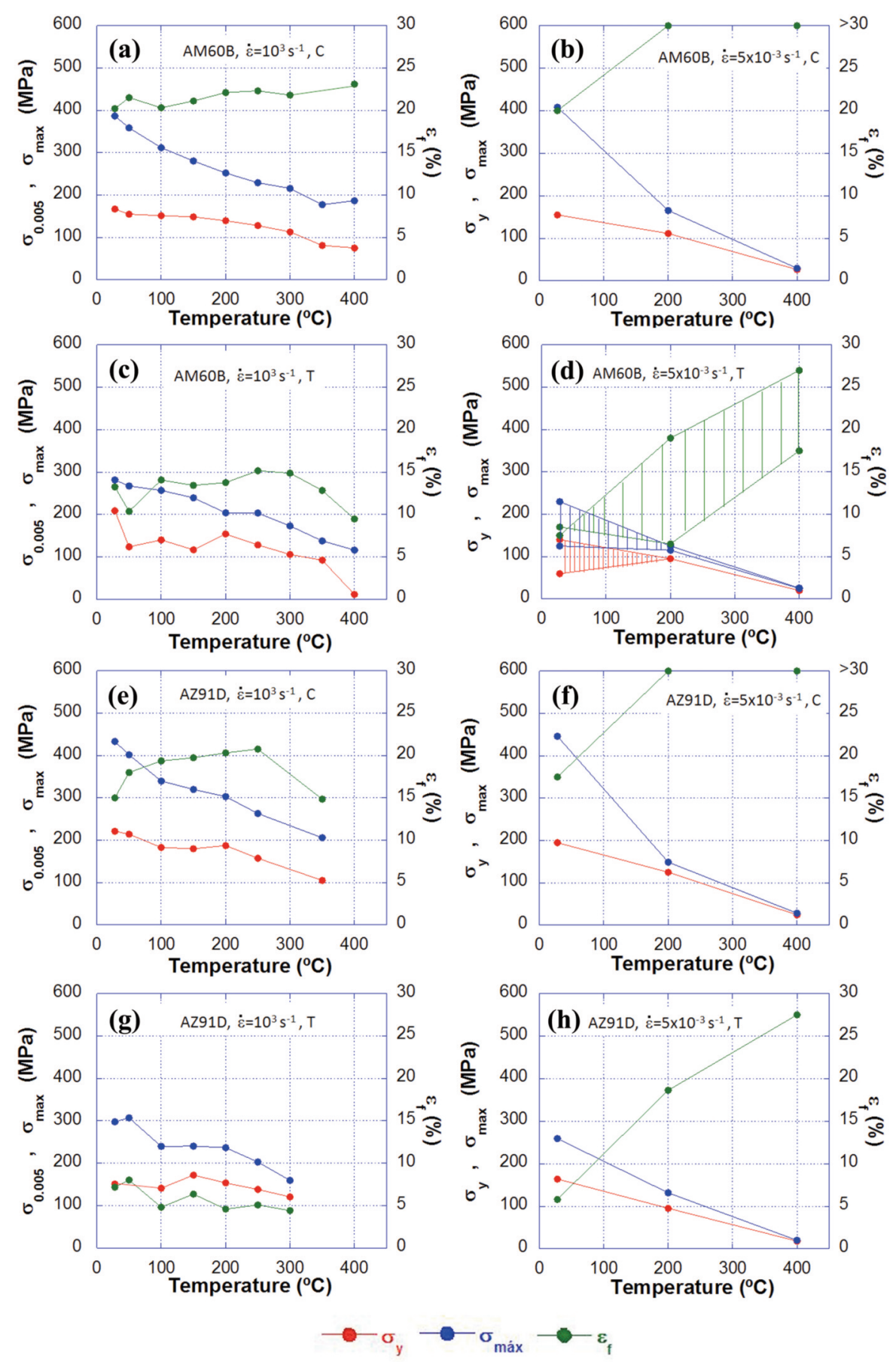

Figure 2. Variation of the yield stress $\left(\sigma_{0.005}\right)$ and of the flow stress $\left(\sigma_{\max }\right)$ with temperature during high $\left(10^{3} \mathrm{~s}^{-1}\right.$, left column) and low $\left(5 \times 10^{-3} \mathrm{~s}^{-1}\right.$, right column) strain rate tests in die-cast AM60B and AZ91B alloys: (a) AM60B, $10^{3} \mathrm{~s}^{-1}$ in compression; (b) AM60B, $5 \times 10^{-3} \mathrm{~s}^{-1}$ in compression; (c) AM60B, $10^{3} \mathrm{~s}^{-1}$ in tension; (d) AM60B, $5 \times 10^{-3} \mathrm{~s}^{-1}$ in tension; (e) AZ91D, $10^{3} \mathrm{~s}^{-1}$ in compression; (f) AZ91D, $5 \times 10^{-3} \mathrm{~s}^{-1}$ in compression; (g) AZ91D, $10^{3} \mathrm{~s}^{-1}$ in tension; (h) AZ91D, $5 \times 10^{-3} \mathrm{~s}^{-1}$ in tension.

Figura 2. Variación del límite elástico $\left(\sigma_{0.005}\right)$ y de la tensión máxima $\left(\sigma_{\max }\right)$ con la temperatura durante ensayos a alta $\left(10^{3} \mathrm{~s}^{-1}\right.$, columna izquierda) y baja $\left(5 \times 10^{-3} \mathrm{~s}^{-1}\right.$, columna derecha) velocidad de deformación en las aleaciones de magnesio coladas por inyección AM60B y AZ91D: (a) AM60B, $10^{3} \mathrm{~s}^{-1}$ en compresión; (b) AM60B, $5 \times 10^{-3} \mathrm{~s}^{-1}$ en compresión; (c) AM60B, $10^{3} \mathrm{~s}^{-1}$ en tensión; (d) AM60B, $5 \times 10^{-3} \mathrm{~s}^{-1}$ en tensión; (e) AZ91D, $10^{3} \mathrm{~s}^{-1}$ en compresión; (f) AZ91D, $5 \times 10^{-3} \mathrm{~s}^{-1}$ en compresión; (g) AZ91D, $10^{3} \mathrm{~s}^{-1}$ en tensión; (h) AZ91D, $5 \times 10^{-3} \mathrm{~s}^{-1}$ en tensión. 
that the presence of a network of low melting point second phases $\left(\mathrm{Al}_{12} \mathrm{Mg}_{17}\right)$ improves the casting properties of the material by suppressing microporosity. Since the AZ91 alloy has a higher alloying content, this effect should be enhanced in this material when compared to the AM60 alloy ${ }^{[29]}$. Finally, in the dynamic tests the scatter in the tensile ductility is significantly smaller. This might suggest that the formation of adiabatic shear bands, the precursors to failure in most metals at impact strain rates, is rather independent of the porosity distribution.

Figure 3 compares the compression stress-strain curves corresponding to the die-cast AM60 (Figs. 3a) and 3b)) and AZ91 (Figs. 3 c) and 3 d)) specimens tested at dynamic (Figs. 3 a) and 3 c)) and quasi-static rates (Figs. $3 \mathrm{~b}$ ) and $3 \mathrm{~d}$ )) and at temperatures ranging from $25^{\circ} \mathrm{C}$ to $400{ }^{\circ} \mathrm{C}$.

In both alloys, the low strain rate curves at room temperature have a "concave-up" shape (at the early stages of deformation), revealing the activation of tensile twinning and slip. As temperature increases and secondary slip systems become operative, the twinning activity decreases significantly and the shape of the curve changes to "concave-down". This effect has been observed in numerous occasions ${ }^{[14]}$. Under dynamic conditions, the curves tend to retain the "concave-up" shape up to higher temperatures than at low strain rates. This is consistent with the activation of twinning at high temperatures under dynamic conditions observed earlier ${ }^{[14-17]}$.
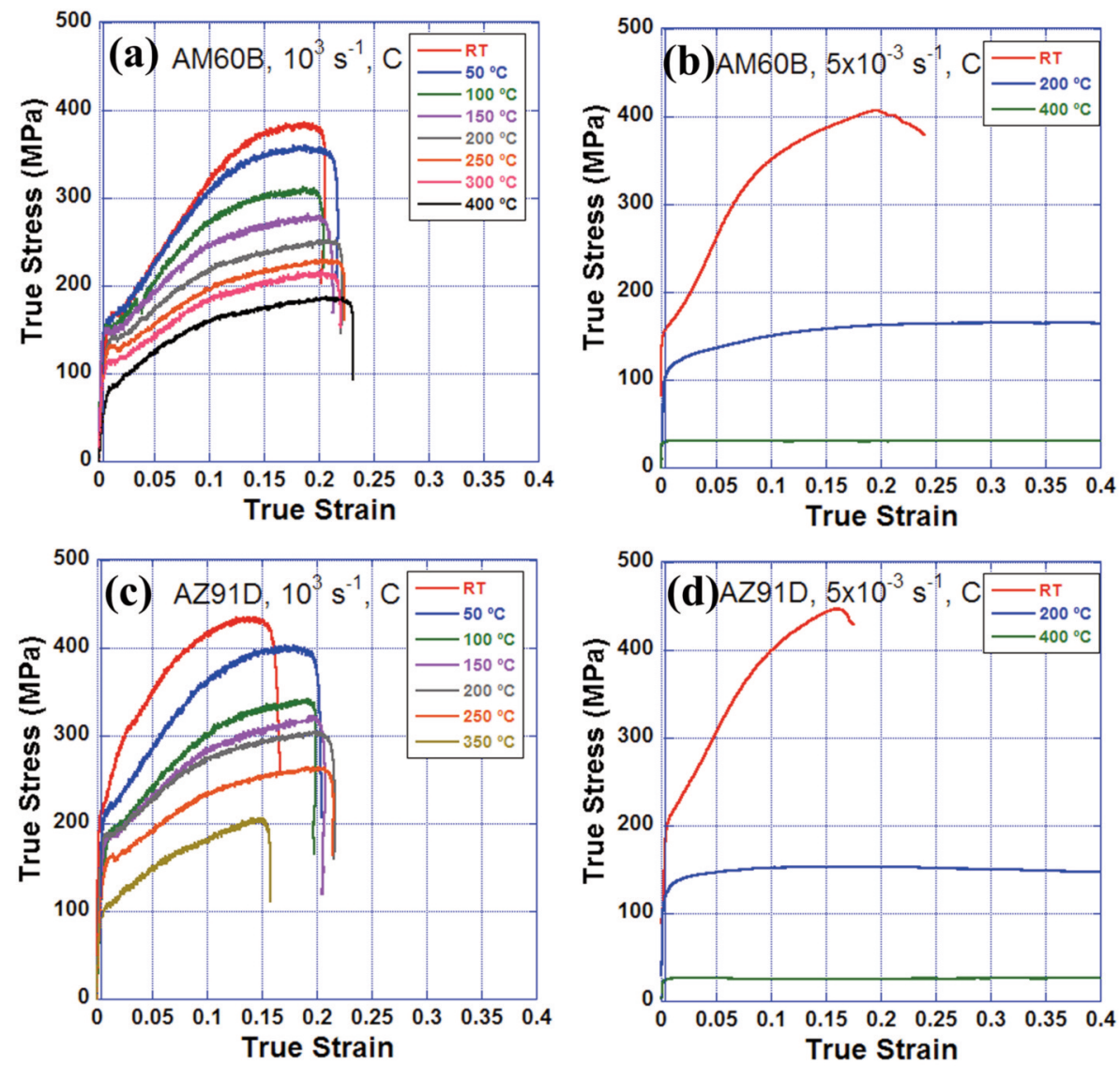

Figure 3. True stress-true strain curves corresponding high $\left(10^{3} \mathrm{~s}^{-1}\right)$ and low $\left(5 \times 10^{-3} \mathrm{~s}^{-1}\right)$ strain rate tests performed in compression at different temperatures in die-cast magnesium alloys: (a) AM60B, $10^{3} \mathrm{~s}^{-1}$; (b) AM60B, $5 \times 10^{-3} \mathrm{~s}^{-1}$; (c) AZ91D, $10^{3} \mathrm{~s}^{-1}$; (d) AZ91, $5 \times 10^{-3} \mathrm{~s}^{-1}$.

Figura 3. Curva tensión verdadera - deformación verdadera correspondiente a los ensayos a alta $\left(10^{3} \mathrm{~s}^{-1}\right)$ y a baja $\left(5 \times 10^{-3} \mathrm{~s}^{-1}\right)$ velocidad de deformación realizados en compresión a diferentes temperaturas en aleaciones de magnesio coladas por inyección: (a) AM60B, $10^{3} \mathrm{~s}^{-1}$; (b) AM60B, $5 \times 10^{-3} \mathrm{~s}^{-1}$; (c) AZ91D, $10^{3} \mathrm{~s}^{-1}$; (d) AZ91, $5 \times 10^{-3} \mathrm{~s}^{-1}$. 
It must be noted that the shape of the tension stress-strain curves, not shown here for the sake of brevity, both at dynamic and quasi-static rates, was always "concave-down" in both alloys. Thus, the activity of tensile twinning seems to be higher in compression than in tension tests. This is consistent with the fact that the volume fraction of material with c-axes tilted more than $45^{\circ}$ away from the loading axis is higher than the fraction of material with tilt angles smaller than $45^{\circ}$ ( $70 \%$ vs. $30 \%$ ), as twinning is a polar mechanism ${ }^{[30]}$.

\section{CONCLUSION}

In summary, the dynamic behavior of the die-cast AM60 and AZ91 alloys has been investigated in a wide range of temperatures and compared to the quasi-static behavior. The texture of the die-cast alloys is not random and this results in a tension-compression asymmetry. It has been found that both alloys possess very good energy absorption capacity, since the yield and maximum strengths do not decrease with increasing temperature as dramatically as at quasi-static rates and the strain to failure values remain fairly constant. The absence of any significant variability in the tensile ductility at dynamic rates is attributed to the independence of the adiabatic shear failure mechanism of the porosity distribution. Tensile twinning is the predominant deformation mechanism at dynamic rates in compression even at temperatures as high as $400^{\circ} \mathrm{C}$.

\section{Acknowledgement}

The authors thank the vehicle interior manufacturer, Grupo Antolín Ingeniería, S.A (MAGNO2008. 1028-CENIT project). Assistance from M. J. Pérez (UPM, Madrid) with the mechanical testing is greatly appreciated as well as Dr. S. Rao Bonta for technical support. The CAI X-ray Diffraction of the Complutense UCM in Madrid, Spain, is kindly acknowledged.

\section{REFERENCES}

[1] H. E. Friedrich and B. L. Mordike, Magnesium Technology: Metallurgy, Design Data, Applications, Springer Verlag, BerlinHeidelberg, Germany, 2006.

[2] S. G. Lee, G. R. Patel, A. M. Gokhale, A. Sreeranganathan and M. F. Horstemeyer, Scripta Mater. 53 (2005) 851-856.
[3] J. P. Weiler and J. T. Wood, Mater. Sci. Eng. 527 (2009) 25-31.

[4] J.P. Weiler and J.T. Wood, Mater. Sci. Eng. 527 (2009) 32-37.

[5] C. D. Lee, Mater. Sci. Eng. 454-455 (2007) 575-580.

[6] J. P. Weiler, J. T. Wood, R. J. Klassen, E. Maire, R. Berkmortel and G. Wang. Mater. Sci. Eng. 395 (2005) 315-322.

[7] Y. H. Wei, L. F. Hou, L. J. Yang, B. S. Xu, M. Kozuka and H. Ichinose, J. Mater. Process. Tech. 209 (2009) 3278-3284.

[8] D. G. L. Prakash, D. Regener and W. J. J. Vorster, J. Alloys Compd. 470 (2009) 111-116.

[9] J. Song, S. M. Xiong, M. Li and J. Allison, J. Alloys Compd. 477 (2009) 863-869.

[10] C. Dørum, O. S. Hopperstad, T. Berstad and D. Dispinar, Eng. Fract. Mech. 76 (2009) 2232 2248.

[11] H. Mayer, M. Papakyriacou, B. Zettl and S. E. Stanzl-Tschegg, Int. J. Fatigue 35 (2003) 245-256.

[12] S. G. Lee, A. M. Gokhale, G. R. Patel and M. Evans, Mater. Sci. Eng. 427 (2006) 99-111.

[13] S. G. Lee and A. M. Gokhale, Scripta Mater. 55 (2006) 387-390.

[14] I. Ulacia, N. V. Dudamell, F. Gálvez, S. Yi, M. T. Pérez-Prado and I. Hurtado, Acta Mater. 58 (2010) 2988.

[15] N. V. Dudamell, I. Ulacia, F. Gálvez, S. Yi, J. Bohlen, D. Letzig, I. Hurtado and M. T. PérezPrado, Acta Mater. 2011, in press.

[16] K. Ishikawa, H. Watanabe and T. Mukai, Mater. Lett. 59 (2005) 1511.

[17] K. Ishikawa, H. Watanabe and T. Mukai, J. Mater. Sci. 40 (2005) 1577.

[18] H. Watanabe and K. Ishikawa, Mater. Sci. Eng. 523 (2009) 304.

[19] I. Ulacia, C. P. Salisbury, I. Hurtado and M. J. Worswick, J. Mater. Process. Tech. 211 (2011) 830.

[20] E. El-Magd and M. Abouridouane, J. Phys. IV 110 (2003) 15-20.

[21] L. E. Murr and C. Pizaña, Metall. Mater. Trans. A 38 (2007) 2611.

[22] D. L. Zou, L. Zhen, Y. Zhu, C. Y. Xu, W. Z. Shao and B. J. Pang, Mater. Sci. Eng. 527 (2010) 3323.

[23] D. Rittel and Z. G. Wang, Mech. Mater. 40 (2008) 629-635.

[24] G. Wan, B. L. Wu, Y. H. Zhao, Y. D. Zhang and C. Esling. Scripta Mater. 65 (2011) 461-464.

[25] B. L. Wu, G. Wan, Y. D. Zhang and C. Esling. Mater. Lett. 64 (2010) 636-639.

[26] M. T. Tucker, M. F. Horstemeyer, P. M. Gullett, H. El-Kadiri and W. R. Whittington, Scripta Mater. 60 (2009) 182-185. 
DYNAMIC DEFORMATION OF HIGH PRESSURE DIE-CAST MAGNESIUM ALLOYS DEFORMACIÓN DINÁMICA DE ALEACIONES DE MAGNESIO COLADAS POR INYECCIÓN A ALTA PRESIÓN

[27] W. Q. Song, P. Beggs and M. Easton, Mater. Design. 30 (2009) 642-648.

[28] Mtex Software, R. Hielscher, TU Chemnitz, Germany.
[29] I. J. Polmear, Light Alloys, Edward Arnold, London, UK, 1989, p. 190.

[30] J. W. Christian and S. Mahajan. Prog. Mater. Sci. 39 (1995) 1. 